\title{
Histological Studies of the Thyroid Gland of the Mouse After Castration
}

\author{
Shunro Ohida \\ Department of Anatomy, Nagoya University school of Medicine, Nagoya \\ (Directors: Profs. Drs. H. Nagamatsu and Ch. Togari) \\ Nine Figures \\ Introduction
}

Up to the present time, many papers have been published on the relationship between the thyroid gland and the gonads, but these are chiefly confined to the gross anatomical, physiological, biochemical and clinical aspects. These pioneer studies have created an urgent need for precise histological evidence of the results obtained. The literature on the histology of mammalian thyroid glands following castration is relatively scarce (see Bargmann, '39), much less complete than might be expected, and concerned mainly with that after ovariectomy. Furthermore, the literature has not provided consistent results sufficient for establishing a generalization, while the data have included two opposing views and an intermediate one: (1) Castration induces the thyroid gland to decreased activity, or (2) to increased activity. (3) Castration leaves no marked effect upon the thyroid gland. In general agreement with the possibilities suggested by Bargmann('39), the diversity of the data may be attributed to the species of experimental animals chosen, age at time of castration and duration of castration period. In addition; the means used previously for histological criteria may have been so inadequate that definite conclusions are not possible. With these factors in mind, the present study was undertaken with the hope of obtaining histological evidence to substantiate the other related observations, as well as to enhance knowledge of the sequelae in thyroid glands of mice of both sexes to castration.

\section{Materials and Methods}

The general plan of experiments was as follows: A total of 257 mice including controls, almost equally divided into males and females 
were used (table 1). Castration was performed in two series for comparison, designated as early adult (50 days of age) and late adult castration (100 days of age). Castrates were autopsied at various intervals (early after the castration, 5 to 10 days; later, 20 to 30 days or more), and along this experimental plan normal controls ranging in age from shortly after birth to 250 days were also autopsied at corresponding ages with almost the same intervals.

Table 1. Numbers of mice examined

\begin{tabular}{|c|c|c|c|c|c|c|c|c|}
\hline \multirow[t]{2}{*}{$\begin{array}{c}\text { Age } \\
\text { in days }\end{array}$} & \multicolumn{2}{|c|}{$\begin{array}{l}\text { Normal } \\
\text { controls }\end{array}$} & \multicolumn{2}{|c|}{$\begin{array}{l}\text { Early adult } \\
\text { castrates }\end{array}$} & \multicolumn{2}{|c|}{$\begin{array}{l}\text { Late adult } \\
\text { castrates }\end{array}$} & \multicolumn{2}{|c|}{$\begin{array}{l}\text { Sham operated } \\
\text { controls }\end{array}$} \\
\hline & $\mathbf{F}$ & $\mathbf{M}$ & $\mathbf{F}$ & $\mathbf{M}$ & $\mathbf{F}$ & $\mathbf{M}$ & $\mathbf{F}$ & $\mathbf{M}$ \\
\hline $3-50$ & 8 & 8 & & & & & & \\
\hline 55 & 1 & 1 & 1 & 1 & & & & 1 \\
\hline 60 & 1 & 2 & 1 & 1 & & & & 1 \\
\hline 65 & 1 & & 1 & 2 & & & & 1 \\
\hline 70 & 1 & 3 & 2 & 2 & & & & \\
\hline 75 & 2 & 2 & 4 & 1 & & & & \\
\hline 80 & 2 & 2 & 1 & 2 & & & & 1 \\
\hline 90 & 2 & 3 & 2 & 2 & & & & 1 \\
\hline 100 & 3 & 2 & 3 & 2 & & & & 1 \\
\hline 102 & & & & & 1 & 1 & & 1 \\
\hline 105 & & & & & 2 & 2 & & \\
\hline 110 & 2 & 3 & 2 & 3 & 2 & 3 & 1 & 1 \\
\hline 114 & & & & & 1 & 1 & & \\
\hline 120 & 3 & 3 & 2 & 2 & 2 & 2 & & \\
\hline 130 & 2 & 2 & 3 & 1 & 1 & 5 & & \\
\hline 140 & 2 & 2 & 2 & 2 & 4 & 3 & & \\
\hline 150 & 2 & 1 & 1 & 2 & 3 & 2 & 1 & \\
\hline 160 & & & 1 & 1 & 2 & 2 & & \\
\hline 170 & 2 & 2 & 3 & 3 & 1 & 2 & & \\
\hline 180 & 1 & 2 & & 4 & 3 & 4 & & \\
\hline 190 & 1 & 2 & & 1 & 2 & & & \\
\hline 200 & 2 & 2 & 1 & 4 & 1 & 4 & & \\
\hline 210 & 1 & & & 2 & & 2 & & \\
\hline 220 & & & & & 3 & 6 & & \\
\hline 230 & & & 2 & & 3 & 1 & 2 & \\
\hline 240 & & & & & & 1 & & \\
\hline 250 & 1 & 2 & 1 & 1 & & 3 & & \\
\hline 270 & & & & & 4 & & & \\
\hline 280 & & & & & 2 & 2 & & \\
\hline 290 & & & & & 2 & & & \\
\hline 300 & & & & 1 & 1 & & & \\
\hline 370 & & & & & 2 & & & \\
\hline Total & 40 & 44 & 33 & 40 & 42 & 46 & 4 & 8 \\
\hline
\end{tabular}

F: Female. M: Male. 
Ether was uniformly used to induce and maintain anesthesia. The males were bilaterally castrated through a midline abdominal incision and the females were operated so, pulling the ovaries into the operative field by traction on the uterine horns and oviducts. To check possible effects on the thyroid glands due to operative trauma, sham operations were performed in a number of animals as shown in table 1. The gonads were lifted through the incision, with partial resection of the peritoneum, and replaced in the animals. Experimental animals and their corresponding controls were kept in the same cages and maintained on the same diet.

Although the operations were carried out with cleanliness, no special care was taken to prevent infection for mice are immune to operative infections. The ovarian pedicle was crushed since it was not found necessary to ligate, but the spermatic cord was found necessary to ligate the stump to prevent bleeding. Serious problem was not presented by hemorrhage or postoperative shock. The animals were as healthy when autopsied as at the time of surgery and showed no evidence of infection within the abdominal cavity. Upon autopsy, complete removal of the gonads was confirmed by visual inspection of the gonadal area and by subsequent macroscopic examination of the external features of the accessory reproductive organs, and and further by histological examination of all questionable tissues.

Immediately after autopsy, thyroid glands were removed, with the trachea and oesophagus, and fixed in the following fluids: Zenker's, Ciaccio's, Bouin's fluids and Müller-formol for general observations, and Kolster's fluid for detail cytological examination. The materials were imbedded in paraffin, sectioned at $6 \mu$ transversely and mounted serially. The sections were stained chiefly with Heidenhain's iron hematoxylin, and some with Mayer's hematoxylin and eosin, and with Azan stain.

The histometrical measurements for the various components of the thyroid glands were made exclusively on the middle one-third of the lateral lobe. They will serve as good histological indices for the functional phases induced by castration of the thyroid glands. In the graphs (figs. 1 to 3 ) each point represents the observation based upon one animal.

The frequency per $\mathrm{mm}^{2}$ of occurrence of follicles over $50 \mu$ in diameter was calculated as follows: The number contained within 20 sections consisting of every 5th section was examined and the averaged number per $\mathrm{mm}^{2}$ was determined by the ratio, frequency averaged per section/averaged section area (fig. 1). 
The averaged diameters of the 20 largest follicles in the peripheral and central zones of the glands, respectively, which were regarded as representative, were estimated per animal per stage by measuring their long and short diameters, and again averaged in groups per stage, and the mean values (long and short diameters /2) are shown in table 2.

In order to obtain some quantitative expression of the serial changes of colloid, the following crude analysis was made with Kolsterfixed preparations stained with iron hematoxylin. An evenness or spottiness of staining between the extremes (blue-black in the whole area within follicles and uniformly faintly gray) was for convenience reckoned as moderately stained colloid. In 20 fields of every 5th section, under low magnification (ocular $\times 8$, objective $\times 40$ ), follicles containing colloid of three staining orders, respectively, were counted. The total in each animal at different stages was averaged and the percentages of the three orders were derived. In the graph (fig. 2), the percentages of follicles containing darkly stained colloid were plotted, and, to avoid congestion of the graph, the other two kinds were omitted. The percentages do not represent the exact rate of colloid changes but give an approximate indication of colloid change which is useful for criteria. The frequency of occurrence of intracolloidal vacuoles (marginal vacuoles, Randvakuolen) was counted in 20 random fields at high magnification (ocular $\times 8$, objective $\times 100$, oil immersion) (fig. 3).

In the present experiments, female animals did not differ in histological findings from males. Therefore, in the observations, the animals are classed together as controls and castrates, no distinction being made as regards sex unless otherwise stated.

\section{Observations}

\section{Follicles}

The majority of large follicles were always located in the peripheral zone of the gland and small follicles chiefly in the central zone, as was recorded in rats (Jackson, '16; Sugiy a ma, '39). Follicles were generally round to oval in shape. Irregular-shaped follicles which have been interpreted as a sign of increased activity, especially for colloid release (A ron, '30, guinea pigs; Sugiy ama, '39, rats; Sugiy ama and Yagizawa, '50, rabbits), were relatively often seen. 


\section{Normal control series}

The thyroid glands shortly after birth to until the 20th day consisted of small follicles and solid follicles without colloid, and they had no follicles exceeding $50 \mu$ in diameter, if any, in small numbers (below 10 per $\mathrm{mm}^{2}$ ). Shortly before puberty (approximately 30 days of age), follicles exceeding $50 \mu$ increased abruptly in frequency per $\mathrm{mm}^{2}$ and reached an initial maximum level (about 30 to 40 per $\mathrm{mm}^{2}$ ) during the 60 th to 80th days, due to their marked occurrence throughout the whole area of the gland. Through an indistinct decrease with considerable fluctuations in the frequency, they showed again a slow increase from about the 180th day on (fig. 1).

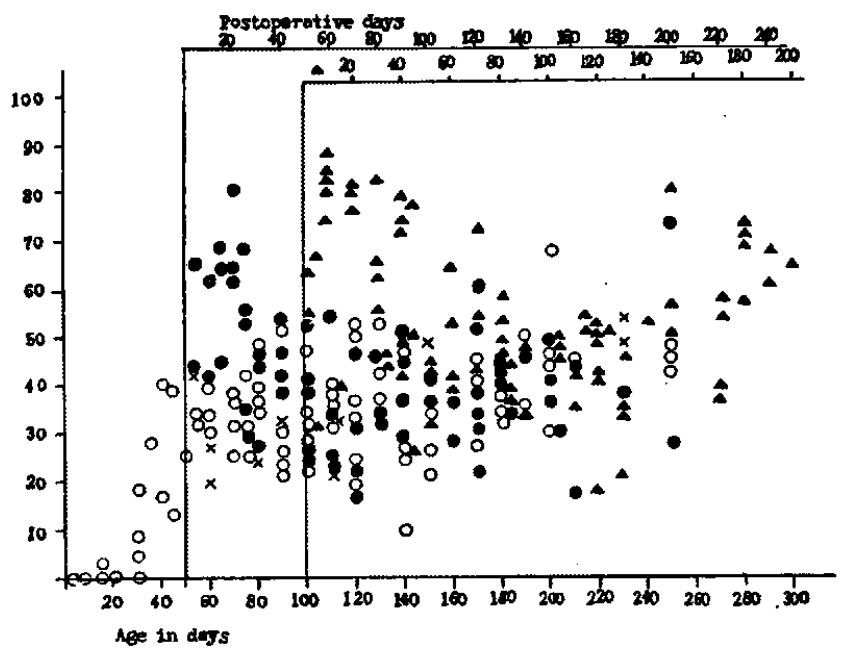

Fig. 1 Frequencies averaged per $\mathrm{mm}^{2}$ of follicles exceeding $50 \mu$ in diameter in the normal control, sham operated control, early adult and late adult castration series.

Note: Open circle: normal control; cross: sham operated control; solid circle: early adult castrate; solid triangle: late adult castrate.

The averaged diameters of the largest follicles in the peripheral and central zones of the gland, respectively, were examined at each age (table 2). The diameters were increased with age, especially from the 30th day on. They indicated always greater values at the periphery than in the center, except soon after birth, the values in the former zone being generally over $75 \mu$, and those in the latter below $70 \mu$.

Irregular-shaped follicles increased significantly during the period from the 90 th to 130 th days. 
S. Ohida

Table 2. Averaged diameters (long and short diameters/2) of the 20 largest follicles regarded as representative in the peripheral and central zones, respectively, in the normal control, early adult and late adult castration series

\begin{tabular}{|c|c|c|c|c|c|c|c|c|}
\hline $\begin{array}{l}\text { Nor } \\
\text { age in } \\
\text { days }\end{array}$ & $\begin{array}{c}\text { mal control } \\
\text { peripheral } \\
\text { zone }\end{array}$ & $\begin{array}{l}\text { series } \\
\text { central } \\
\text { zone }\end{array}$ & $\begin{array}{l}\text { Early adu } \\
\text { days after } \\
\text { castration }\end{array}$ & $\begin{array}{l}\text { Ut castration } \\
\text { peripheral } \\
\text { zone }\end{array}$ & $\begin{array}{l}\text { series } \\
\text { central } \\
\text { zone }\end{array}$ & $\begin{array}{l}\text { Late adu } \\
\text { days after } \\
\text { castration }\end{array}$ & $\begin{array}{c}\text { lt castration } \\
\text { peripheral } \\
\text { zone }\end{array}$ & $\begin{array}{l}\text { series } \\
\text { central } \\
\text { zone }\end{array}$ \\
\hline 3 & $26 \mu$ & $26 \mu$ & & & & & & \\
\hline 8 & 36 & 31 & & & & & & \\
\hline 20 & 49 & 31 & & & & & & \\
\hline 30 & 76 & 44 & & & & & & \\
\hline 55 & 75 & 61 & 5 & 79 ע. & $55 \mu$ & & & \\
\hline 60 & 96 & 76 & 10 & 100 & 60 & & & \\
\hline 70 & 87 & 67 & 20 & 89 & 65 & & & \\
\hline 80 & 82 & 64 & 30 & 87 & 66 & & & \\
\hline 90 & 61 & 49 & 40 & 84 & 58 & & & \\
\hline 100 & 72 & 58 & 50 & 86 & 62 & & & \\
\hline 110 & 86 & 57 & 60 & 88 & 63 & 10 & $71 \mu$ & $78 \mu$ \\
\hline 120 & 85 & 62 & 70 & 82 & 64 & 20 & 117 & 109 \\
\hline 130 & 75 & 65 & 80 & 105 & 64 & 30 & 108 & 91 \\
\hline 140 & 89 & 63 & 90 & 93 & 72 & 40 & 102 & 88 \\
\hline 150 & 86 & 62 & 100 & 89 & 65 & 50 & 94 & 70 \\
\hline 170 & 89 & 66 & 120 & 91 & 63 & 70 & 83 & 71 \\
\hline 200 & 101 & 65 & 150 & 87 & 58 & 100 & 98 & 89 \\
\hline 230 & & & 180 & 94 & 60 & 130 & 124 & 91 \\
\hline 250 & 95 & 59 & 200 & 107 & 61 & 150 & 132 & 90 \\
\hline 300 & & & 250 & 110 & 75 & 200 & 140 & 79 \\
\hline
\end{tabular}

Early adult castration series

The same sequence of quantitative observations of serial changes of follicles over $50 \mu$ was repeated with this series. Immediately after castration, the frequency initiated an abrupt increase to a maximum level $\left(60\right.$ to 70 per $\mathrm{mm}^{2}$ ) during the 10th to 20th postoperative days ( 60 to 70 days of age). The value was about one and half times that (30 to 40 per $\mathrm{mm}^{2}$ ) of the corresponding normal controls (figs. 1 and 5). From about the 30th postoperative day ( 80 days of age) the frequency decreased rapidly to that of the corresponding normal controls (25 to 45 per $\mathrm{mm}^{2}$ ), and remained at almost the same level until the 100 th postoperative day (150 days of age). Associated with other changes, this imparted an almost normal appearance to the glands (figs. 6 and 7). From the 120th postoperative day, the frequency again increased slowly being included within that of the normal control. There were some values elevated more in the frequency during the 100th to 150th postoperative days and other small values during the 160th to 200th postoperative days. The small values were produced by the 
marked occurrence per unit area of enormously grown follicles.

The averaged diameters of the largest follicles showed little differences from those of the normal control series (table 2). Further examination of the data as indicated in table 2 reveals that the largest follicles observed in the peripheral zone indicated slightly elevated values $(79-100-89 \mu) 5$ to 20 days after castration and the highest values $(107-110 \mu) 200$ to 250 days after castration, while those found in the central zone remained almost unchanged.

Irregular.shaped follicles increased significantly during the 10th to 30th postoperative days (60 to 80 days of age) and again during the 60 th to 80 th postoperative days (110 to 130 days of age). Papillary projections of follicle walls rarely extended into the lumina of collapsed follicles.

\section{Late adult castration series}

A similar though more enhanced change was observed in the follicular pattern. The frequency per $\mathrm{mm}^{2}$ of occurrence of follicles exceeding $50 \mu$ in diameter assumed an almost same manner in sequence as that of the early adult castration series (figs. 1 and 8).

Shortly after castration the frequency increased abruptly and attained a maximum level $\left(80\right.$ per $\left.\mathrm{mm}^{2}\right)$ at about the 10 th postoperative day (110 days of age), which was two times or more the value ( 30 to 40 per $\mathrm{mm}^{2}$ ) of the corresponding normal controls and higher than that of the comparable early adults castrates. Until about the 40th postoperative day ( 140 days of age) the level was maintained. About the 40th postoperative day, the frequency decreased rapidly to the normal control and remained at almost the same level as normal until about the 110th postoperative day (210 days of age) ( 35 to 45 per $\mathrm{mm}^{2}$ ). From the 120th postoperative day (200 days of age) the frequency indicated a slow increase. A higher incidence of small values in the frequency was encountered after the 120th postoperative day, and was an expression of variations in which enormously grown follicles were increased per unit area.

The averaged diameters of the largest follicles in the peripheral zone as well as in the central zone were greater than those of the corresponding normal controls and larger than those of the comparable early adult castrates (table 2). The diameters were significantly increased soon after castration (peripheral : 117-108 $\mu$; central : $109-91$ $\mu$ ) and again 130 to 200 days after castration (peripheral : 124-140 $\mu$; central : $91-79 \mu$ ). 
Irregular-shaped follicles appeared most numerous during the 10th to 20th postoperative days (110 to 120 days of age) at the gland periphery as well as in the center.

\section{Sham operated control series}

This series showed no noticeable difference in follicular pattern from the normal intact control series (fig. 1).

\section{Follicle Cells}

Follicle cells varied in height and from in different follicles and so depended upon age, glandular zones and duration of castration period. Their surfaces were connected by well-defined terminal bars. Nuclei of the general follicle cells were round to oval except in squamous follicle cells, and located somewhat centrally or basally in the cell body. Their chromatin reticulum was moderately dense. A number of .hyperchromatic nuclei whose chromatin reticulum was completely obscure with iron hematoxylin but not pyknotic, were often found. Besides these nuclei, there were much large nuclei whose chromatin reticulum was moderately dense. The cytoplasm was finely granular and its granularity of various degrees led follicle cells to assume different forms from swollen clear cells to darkly stained cell.

Some of the follicle cells were loaded with several secretory droplets of various shades of black with iron hematoxylin or blue with Azan stain (fig. 9). The droplets were of various sizes and appeared chiefly in the supranuclear zone. The preparations fixed in Kolster's or Ciaccio's fluid were very useful in preserving the secretory droplets, while those in Zenker's fluid were not.

Mitotic figures of follicle cells were rarely found.

\section{Normal control series}

Until the 20th day after birth, swollen cubical to low columnar follicle cells were limited to the peripheral zone of the gland, while low cubical cells were seen very often in the central zone. After a while, this pattern was gradually reversed; the subsequent reversed pattern was maintained almost throughout life. During the period from the 30th to 80th days, cubical follicle cells prevailed over the whole area of the gland.

From approximately the 100th day the follicle cells found in the central zone increased significantly in height with variability in cell form and nuclear size. Among them, swollen cubical cells were found in 
abundance, and some of them became much clear. After the 200th day, they were changed to squamous to cubical types which were observed in the peripheral zone. Secretory droplets were rarely found during the 70 th to 190 th days $(70,80,90,100,110$ and 190 days of age), during which time the colloid was labile in staining property (table 3).

Table 3. Percentages of occurrence of secretory droplet-positive cases during different stages in the early adult and late adult castration series (Kolster-fixed and Ciaccio-fixed preparations)

\begin{tabular}{cccc}
\hline $\begin{array}{c}\text { Normal control } \\
\text { series }\end{array}$ & $\begin{array}{c}\text { Days after } \\
\text { castration }\end{array}$ & $\begin{array}{c}\text { Early adult castration } \\
\text { series }\end{array}$ & $\begin{array}{c}\text { Late adult castration } \\
\text { series }\end{array}$ \\
\hline Total $11 \%(7 / 64)$ & & $55 \%(30 / 55)$ & $41 \%(26 / 64)$ \\
\hline & $\begin{array}{r}-30 \\
-40\end{array}$ & $70 \%(12 / 17)$ & \\
& $11 \%(7 / 64)^{*}$ & $50-120$ & $65 \%(11 / 17)$ \\
$40-120$ & $53 \%(16 / 30)$ & $22 \%(7 / 32)$ \\
& $120-$ & $25 \%(2 / 8)$ & $53 \%(8 / 15)$ \\
\hline
\end{tabular}

Note: Ratios in parentheses indicate no. of droplet-positive cases/no. of cases examined.

* Seven droplet-positive cases were found during the period from 70 to 190 days of age.

\section{Early adult castration series}

Immediately after castration follicle cells were low columnar throughout the whole area of the gland, but, at about the 20th postoperative day (70 days of age) when large follicles over $50 \mu$ increased rapidly in frequency per $\mathrm{mm}^{2}$, they were temporarily low. Associated with the subsequent rapid decrease in the frequency of the large follicles, they increased significantly in height again, and remained as well until about the 80th postoperative day; most of them projected their apical portions into the follicle cavity in the peripheral zone as well as in the central zone. Some of them were extremely swollen and rounded, and others contained large nuclei in clear cell bodies. From about the 120th postoperative day (170 days of age) on, they decreased in height in the large follicles situated in the periphery of the gland, and later, in the center also.

Secretory droplets appeared in abundance in the majority of the cases (table 3 ), and most frequently at 10 to 20 days after castration. They occurred generally in the supranuclear zone, but were found rarely 
in the basal zone during the 30th to 80 th postoperative days. Some of them attained diameters of two or three $\mu$.

\section{Late adult castration series}

That follicle cells, collectively, are lower in height in the late adult than in the early adult castration series, was recognized throughout the study of successive stages of the castration period. The follicles cells, however, indicated the same sequential changes in principle as those of the early adult castration series.

İmmediately after castration follicle cells were low columnar, and soon became lower in height with the marked increase in frequency per $\mathrm{mm}^{2}$ of large follicles exceeding $50 \mu$. From about the 40th to 80 th postoperative days ( 140 to 180 days of age) they were swollen throughout the whole area of the gland, and projected their apical portions into the follicle cavity. From about the 120th postoperative day (220 davs of age) on, they tended to decrease in height, especially in the peripheral zone of the gland.

Secretory droplets were seen first 5 days after castration and their maximum occurrence was found during the 10th to 30 th postoperative days (table 3 and fig. 9).

\section{Sham operated control series}

The follicle cells appeared indistinguishable from those of the corresponding normal controls in all respects.

\section{Parafollicular Cells}

The parafollicular cells (Sugiyama, ' 42 , mice) were found relatively of ten throughout the four series. They showed no significant changes in the castration series.

\section{Colloid}

In. Zenker.fixed preparations stained with hematoxylin and eosin, colloid was as a rule not granulated, eosinophilic and rarely partly basophilic and partly eosinophilic. The colloid was stained more intensely in the peripheral zone of the gland. With Heidenhain's iron hematoxylin, differences of staining were more clearly distinct, ranging from blue black in the whole area within the follicles, to faintly gray. With Azan stain, colloid was red to blue in color. Iron hematoxylin stain was found to be superior to other stains for quantitative expression of serial changes of colloid because of the relatively rare occurrence of moderately stained colloid which makes it impossible to 
determine its staining order.

Intracolloidal vacuoles have the appearance of artifacts by fixation, but their numerous occurrence may well bear a relation to colloid release because of their characteristic distribution induced under certain conditions (Krogh and Okkels, '33, guinea pigs; Severinghaus, '33, guinea pigs and monkeys; Aron, '34, guinea pigs; Florentin, Fontaine and Hennequin, '36, rabbits; Sugiyama, '39, rats; Sugiyama and Yagizawa, '50, rabbits), The vacuoles were found numerously in Kolster.fixed preparations and less numerously in Zenkerfixed or Ciaccio-fixed preparations. Furthermore, they occurred in greater degree in feebly stained colloid than in dark, but their numerous occurrence was occasionally seen in large follicles containing dark colloid, which consisted of swollen cubical cells. Crevices which are obviously artifacts made by cutting with the microtome knife but are related to dense colloid, were found in darkly stained colloid contained within medium-sized to large follicles, and infrequent in feebly stained colloid.

\section{Normal control series}

From shortly after birth to about the 50th day, colloid stained darkly in the majority of the cases (fig. 2). From about the 60th day it tended to indicate wide fluctuations in staining, being feeble in major part during the 90th to 130th days.

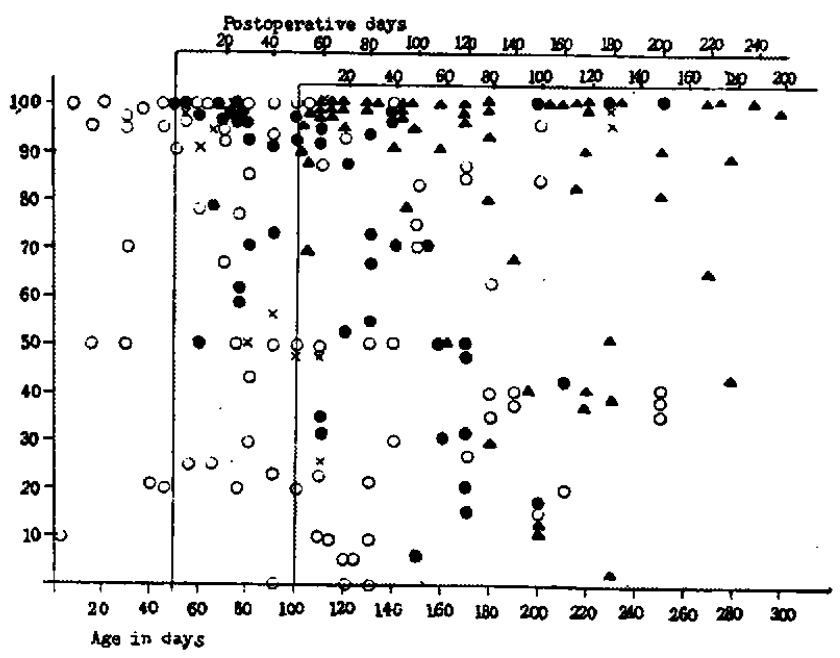

Fig. 2 Percentages averaged per field (ocular $\times 8$, objective $\times 40$ ) of the numbers of follicles containing darkly stained colloid in the normal control, sham operated control, early adult and late adult castration series. 
Intracolloidal vacuoles appeared considerably numerous soon after birth maintaining a high level toward puberty, but reduced at the 60th to 70th days when large follicles over $50 \mu$ reached a transient maximum in frequency per $\mathrm{mm}^{2}$. After this time the vacuoles showed again an increase to reach a subsequent maximum at the 100th day, and again a gradual decrease after the 150th day (fig. 3).

Crevices in colloid did not appear until the 20th day, and they began to appear from the 30th day and reached a maximum in number soon. As vacuolation of colloid increased, they were reduced in number. After the 160th day, they increased slightly in number toward the 250th day.

Desquamated follicle cells found within the follicle cavity were rare.

\section{Early adult castration series}

With an abrupt increase in frequency per $\mathrm{mm}^{2}$ of follicles exceeding $50 \mu$, colloid showed deep staining throughout the whole area of the gland (figs. 2 and 5). This static state in staining was maintained as such until about the 30th postoperative day ( 80 days of age). Then the colloid began to stain feebly in small follicles scattered in the central zone, and fluctuated in staining during the 60th to 100th postoperative days (110 to 150 days of age), resembling that of the corresponding normal controls (figs. 2,6 and 7). In general, feebly stained colloid

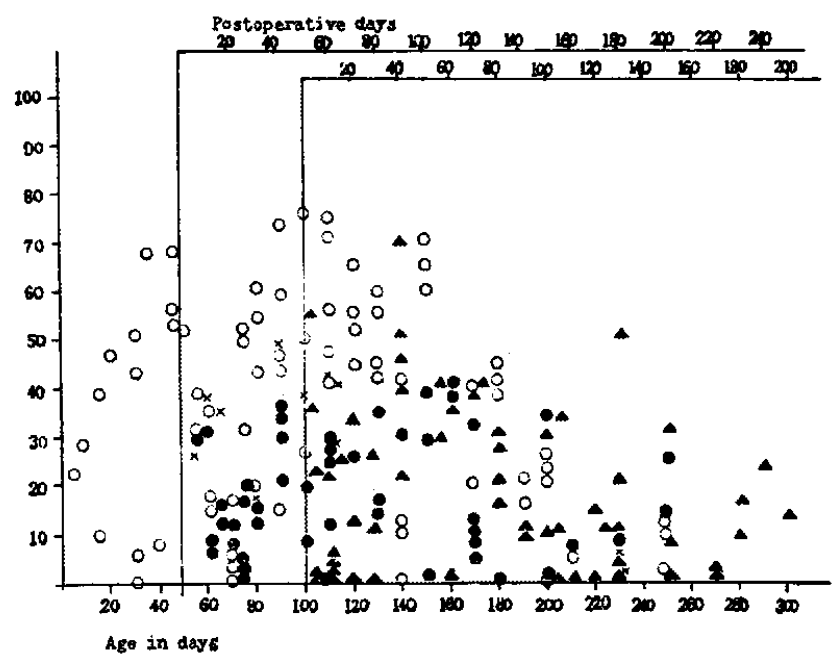

Fig. 3 Frequencies per field (ocular $\times 8$, objective $\times 100$ oil immersion) of intracolloidal vacuoles in the normal control, sham operated control, early adult and late adult castration geries. 
appeared more frequently in female castrates. This period was also associated with the decreased level in frequency per $\mathbf{m m}^{2}$ of large follicles exceeding $50 \mu$, which also resembled the frequency level of the corresponding normal controls. From about the 120th postoperative day, the colloid inclined again to deep staining.

Immediately after castration, vacuoles reduced significantly with enhanced staining of colloid, and reached a minimum level at the 20th postoperative day (70 days of age) (figs. 3 and 5). After a while they began to increase with the occurrence of scattered feeble colloid and attained a maximum level during the 60 th to 100 th postoperative days (110 to 150 days of age), although smaller in number than those of the corresponding normal controls (figs. 3, 6 and 7). After the 130th postoperative day (180 days of age) they were generally small in number and were included within the decreasing range of the normal control series.

Crevices in colloid appeared relatively numerous soon after castra. tion (fig. 5) and were then reduced. Their occurrence except during the initial castration stage, could not be apparently distinguished in number from that of the corresponding normal controls. However, there was found a somewhat higher incidence. Desquamated follicle cells in colloid rarely appeared.

\section{Late adult castration series}

The general staining pattern of colloid in this series contrasted with that of the corresponding normal controls, but was almost the same in principle as that of the early adult castration series. However, the staining degree was enhanced. Soon after castration colloid stained very deeply throughout the whole area of the gland (fig. 8). With the prolongation of the period of maximum increase in frequency per $\mathrm{mm}^{2}$ of large follicles exceeding $50 \mu$, the static condition in staining likewise continued until about the 40th postoperative day (140 days of age), longer than that of the early adult castration series. At about the 100th postoperative day the colloid indicated wide fluctuations in staining, but after the 140th postoperative day it was almost stable in dark staining.

Vacuoles abruptly reduced in number immediately after castration (fig. 8), but increased in number from about the 40th postoperative day (140 days of age) and approached the normal control range during the 40th to 80th postoperative days (140 to 180 days of age). Later, they showed a tendency toward decrease in number with some exceptions 
(fig. 3).

Crevices in colloid appeared markedly at the 10th postoperative day (110 days of age). Afterward they began to decrease and reach a minimum in number at the 50 th postoperative day (150 days of age), but from the 120th postoperative day (220 days of age) they increased again.

\section{Sham operated control series}

The general pattern of colloid in this series could not be apparently distinguished from that of the normal intact control series (figs. 2 and 3 ).

\section{Connective Tissue}

Connective tissue did not show any marked alterations after castration and indicated only the age change of the corresponding controls in the early adult castration series as well as in the late adult. The interlobular connective tissue originated from the glandular capsule was relatively distinct until the 8 th day after birth, but thereafter became indistinct with an abrupt increase in frequency per $\mathrm{mm}^{2}$ of large follicles exceeding $50 \mu$. The incomplete lobulation was at best observed only in the medial peripheral zone of the gland, throughout life. This finding held true for that of castrates corresponding in age. The perifollicular connective tissue was derived from both the indistinct interlobular tissue and capsular connective tissue, and was small in amount and composed of delicate argylophilic fibrils and a few connective tissue cells, without elastic fibers.

Steatoblasts first appeared within the interstitial connective tissue on the third day after birth and increased in number slowly. Most of them contained coarse fatty droplets in great abundance. The steatoblast tissue was especially marked in the medial peripheral zone, upper and lower poles of the lobes, but relatively small in amount in the lateral peripheral zone. Here, follicles were found distinctly separated. At 60 days of age, some of the steatoblasts were transformed into fat cells in normal controls as well as in castrates.

\section{Blood Vessels}

Throughout the four series, all of the vascular patterns of the glands, except for capillary hyperemia, appeared nearly alike.

Arteries of the thyroid glands ran within or beneath the capsule and most of them entered the interior of the glands from the medial zone along the indistinct interlobular connective tissue to ramify into 
smaller branches. Soon after birth they were still undifferentiated but had distinct laminae elasticae interna and externa, first at 20 days of age. Afterward they increased in size still further, and large welldeveloped arteries were found at 140 days. Veins were accompanied. by the arteries. They remained far less-developed shortly after birth and resembled sinusoidal capillaries in structure. First at 60 days the elastic membrane and a small amount of muscle fibers were seen in some of them. Most of the veins remained composed of the delicate intima and adventitia throughout life.

Capillary hyperemia varied in occurrence according to age in the normal control series and periods of castration in the castration series. In the normal control series, capillaries were engorged from the 30th day on and indicated marked hyperemia during the 80th to 130th days, during which colloid was feeble and highly vacuolated. In the castration series, the hyperemia was marked during the period from approximately the 40 th to 80 th postoperative days (90 to 130 days of age; 140 to 180 days). Engorged capillaries became sinusoidal and very often bulged into the follicle walls, indenting their basal surfaces. This arrangement enhanced still further the intimacy of the capillary with the follicle cells.

\section{Discussion}

Florentin ('29) reported briefly that the thyroid gland of guinea pigs is stabilized in appearance after castration. Extirpation of ovaries is followed by accumulation of colloid (Chouke, '30, guinea pigs; Anderson and Kennedy, '33; Benazzi, '33; Schultze, '35, all, rats and mice). Schultze and Turner ('45) stated that less thyroid hormone is secreted by capons than by cockerels. Betz ('52) found in rats that 5-day and 15-day periods of castration inhibit thyroid activity which has increased following total irradiation of animals with sublethal dosages (500 r) and this inhibition is observed equally in either sex. Siegel and D'Angelo ('52), working with rats, reported that a 6 month period of castration results in significant thyroid weight reduction, and diminution in thyroid cell height occurs as early as 4 weeks after the operation and is maintained so in older animals. MergierParot and Tuchmann-Duplessis ('53) described by studies on male rats, that one week period of castration results in diminution in follicle cell height, enlargement of follicles, increase in amount of colloid and its lesser vacuolation. 
Contrary to these data, Loeser ('34, guinea pigs) showed that immediately after removal of the ovary there is transitory histological evidence of thyroid hyperfunction. Proto ('34) and Dogliotti ('34) also proved thyroid activation or hypertrophy after castration. Kippen and Loeb ('36) asserted that castration performed on male or female guinea pigs causes an increased production of thyrotropin by the pituitary, which in turn leads to proliferative activity in the thyroid gland. This consequence, they noted, is less obvious when immature animals are used for the experiments.

Starr and Bruner ('35) failed to find the histological effects exerted by castration upon the thyroid glands of guinea pigs. Paschkis, Cantarow and Peacock ('48) reported no significant effect of castration upon the thyroid glands of rats, as measured by uptake of radioactive iodine. Selye ('50) summarized that castration remains without any striking effect upon the thyroid gland. Morris ('52), by studies on capons, found little or no change in thyroid activity in spite of radical alterations induced by castration of the pituitary. Odell ('52) described that the secretion rate of thyroid hormone in cockerels is not affected by the absence of gonads.

It seems likely that the histological change or the activity found after castration of the thyroid gland may be variable according to certain factors. Ross ('38) stated that castration performed on sexually immature guinea pigs induces accumulation of colloid in the thyroid glands, while cryptorchid castrated animals fail to produce such a phenomenon. Further, he stated that castration induces an atrophy in the thyroid glands of rats.

As concerns the change after castration, the present observations reveal a close association between the thyroid gland and the gonads; the thyroid glands of mice appear to indicate marked a histological pattern other than normal. In comparison with the above reviewed data, the author, however, is inclined to the belief that there are certain common features among the histological findings presented here and certain differences as well. These similarities and diversities are difficult to evaluate qualitatively, and quantitative histometrical methods serve to make them clear.

The histometrical measurements make it possible to divide the sequential progression of histological changes of the thyroid gland of the mouse following castration, into the following three stages. 
First stage

The first stage appears to consist of three distinct phases, sudden accumulation, static storage and abrupt release of much colloid. The thyroid glands are histologically characterized by a sudden rise in frequency per $\mathrm{mm}^{2}$ of large follicles exceeding $50 \mu$, almost static maintenance of their maximum level and subsequent abrupt decrease with irregular becoming in shape (figs. 1,5 and 8). Associated with this, a marked increase, static maximum level and subsequent reduction of darkly stained colloid with marked hyperemia are attended (figs. 2, 5 and 8). Simultaneously, a transient decrease in number and subsequent increase of intracolloidal vacuoles (fig. 3 ), and the reversed relation of occurrence of colloidal crevices are found. During this stage, a marked increase in follicle cell height in relation to colloid accumulation and its release, except in the middle static phase, are revealed. Secretory droplets appear frequently (fig. 9 and table 3).

Apparently there is a time relation concerning the change preseted. Approximately 30 days are required for this stage in the early adult castration series and about 40 days in the same late series. The maximum level per $\mathrm{mm}^{2}$ of large follicles over $50 \mu$ is higher in the late series than in the early series. A concomitant change in colloid staining accords also likewise with the duration of the stage (fig. 2).

The thyroid glands in the corresponding controls including the sham operated group, began to enter a labile stage indicating fluctuations in staining of colloid and numerous occurrence of intracolloidal vacuoles ( 50 to 80 days of age) or they appear to be at the labile stage (100 to 140 days) (figs. 2,3 and 4 ).

Some of the relationships between the gonads and the thyroid gland, if not most of them, may be translated through the pituitarythyroid axis; however, concerning the secretion of thyrotropic hormone by the pituitary in castrated animals, the problem still remains unsettled. In women at the onset of menopause, there is a tendency toward an increased blood iodine concentration (Cucco, '32). It is likely that the menopausal increase in blood iodine concentration reflects increased activity of the thyroid gland through the pituitary, which at this time secretes thyrotropic hormone in excess (Salter, '40). Loeser ('34) found in guinea pigs that in the first two or three weeks after removal of ovaries there is an augmented production and secretion of thyrotropie hormone. Entirely consistent results were obtained by Franke and Ptaszek ('33) in young bitches after castration. A marked in- 
crease in blood iodine was noted within the first week, and within three weeks the level was back to normal. Further, they noted that in old bitches whose ovaries were already nonfunctional no such increase in blood iodine occurs. They ('33) also found a similar effect in male dogs castrated. On the other hand, Purves and Griesbach ('51) suggested little change of thyrotropic hormone potency of the rat pituitary in early gonadal deficiency as well as in late, because of no cytological alterations, and little change of glycoprotein content in thyrotropic basophils. Siegel and D'Angelo ('52) reported that blood TSH titers in castrated rats diminish slightly two weeks and significantly 7 weeks after the operation.

The change of the thyroid gland after the administration of pituitary extract or thyrotropin is observed histologically as follows: elevation of follicle epithelium; less staining, vacuolation and depletion of colloid; and irregular becoming in shape and diminution in size of follicles. Recent work established a relationship between the formation of secretory droplets and thyrotropic hormone. The droplets appear after presumably increased endogenous thyrotropic hormone production caused by partial thyroidectomy (Hürthle. 1894; Ishimaru, '26). In addition, special attention has been directed to the secretory droplets as a basis for thyrotropic hormone assay (De Robertis, '42; De Robertis and Del Conte, '44, guinea pigs). Dvoskin ('47; '48) verified this fact with cockerels and rats.

In connection with the available data, the present results may permit one to state that, the histological change found during the late part of the first stage gives evidence in favour of an increased secretion of thyrotropic hormone by the pituitary. However, the data of the initial part including a sudden rise in accumulation of colloid, cast some doubt upon the justification of this problem. Does the thyrotropic hormone merely accelerate the emptying of thyroid follicles or does it also simultaneously induce the manufacture of new hormone and if so, how? At what rate or to what extent do the both processes proceed? According to Williams' ('37) studies of thyroid implants in rabbits' ears, injections of pituitary extract produce an exaggeration of the normal follicular response which is characterized by an increase in some follicles of the amount of colloid and an increase in most follicles of the rate and extent of colloid release. Which of these or other possibilities are involved in the present data, remain subjects for further study. 
One point of interest is that the thyroid gland stimulated by thyrotropin has an increased avidity for circulating iodide to revert to colloid accumulation. Leblond and Gross ('48), by the use of the coated radioautographic technique, suggested that the deposition of radioactive thyroglobulin formed as granules in the supranuclear zone into colloid is much accelerated in the thyrotropin-treated rats. The secretory droplets presented here may be interpreted as an expression of this mechanism.

To summarize, the first stage, if not the whole part of it, appears to represent a peculiar pattern of the mouse thyroid glands marked by an increased secretion of thyrotropic hormone in the pituitary. According to Hayashi ('53, mice), basophils of the pituitary increase in number after castration, reaching a maximum at the 30th postoperative day, and decrease gradually. This fact seems to have some relation with the present result.

\section{Second stage}

The second stage lasts approximately from the 30th or 40th postoperative day to the 120th postoperative day. The end of this stage is difficult to evaluate accurately; the turning point to the next stage is conveniently determined by the onset of wide-spread occurrence of follicle cells decreased in height. The histological changes in both castration series appear nearly alike in pattern although somewhat different. The decreased frequencies per $\mathrm{mm}^{2}$ of large follicles over 50 $\mu$ in both castration series are within the range of the corresponding normal controls (fig. 1), but irregular-shaped follicles are seen more often in the early adult castration series.

There are still other slight differences among the patterns of both castration series and corresponding normal controls (figs. 2 and 3). The change in the early adult castration series is characterized by a trend toward fluctuations in colloid staining, which resembles that of the normal controls. Coupled with the data of the decreased frequency of the large follicles, an explanation for these fluctuations may be offered by the radioautographic experiments of Nadler, Leblond and Bogoroch ('54) that thyroid function in rats is accelerated in turnover of thyroglobulin in the smaller follicles. The fluctuations may have some relation with a turnover of colloid substance; this fact may be supposed to resemble that of the corresponding normal controls. The change found in the late series appears to be somewhat stable; a higher incidence of darkly stained colloid is observed. That the diameters of 
the largest follicles during this stage is larger in this series than in the early adult castration series is associated with this finding (table 2).

The follicle cells in both castration series. especially in the early series, remained increased in cell height with variability in cell form and nuclear size, and partly with hyperchromatophilia of the nuclei. In marked contrast with the rare occurrence in the corresponding normal controls, secretory droplets are still often found and more frequently in the early adult castration series (table 3). According to Dvoskin ('48), the droplets present in the follicle epithelium of rats exposed to cold or fed thiouracil, promptly disappear following hypophysectomy, and the adrenal or its secretions are not responsible for droplet formation. It seems probable that the frequent occurrence of the droplets during this stage may have certain relation to the pituitary.

In brief, during the second stage the thyroid glands of both castration series resemble in general histological pattern those of the normal control series. This is especially marked in the early adult castration series.

\section{Third stage}

The thyroid glands during this stage are characterized by a slow increase in frequency per $\mathrm{mm}^{2}$ of large follicles over $50 \mu$ within the range of the normal control series (fig. 1), and general decrease in follicle cell height. A significant increase in the diameters of the largest follicles marks also this stage (!), and especially in the late adult castration series (table 2). Concomitant with these phenomena, a sequence from instability to stability in colloid staining and decreas. ing vacuolation of colloid, enhanced accumulation of colloid, are typical of this stage. Despite these usual changes which may be interpreted as decreased thyroid activity, secretory droplets appear still relatively often, especially in the late adult castration series, and are in contrast with the rare occurrence in the corresponding normal controls (table 3 ). The same presumption, as that for the previous stage, may be presented for this finding.

As concerns the thyroid glands of mice after castration, females show almost the same histological changes as those of males; no sex difference is observed in both castration series. However, the occurrence of feebly stained colloid seems to be higher in frequency in females.

Without showing any marked difference, the connective tissue in the castration series undergoes an age change similar to that of the 
normal controls, and the same holds true for the vascular pattern, except for capillary hyperemia which is marked in the first and second stages.

In short, after castration the thyroid glands appear to fluctuate markedly in histological character and the structural modifications reflect changes occurring in the secretory process. Despite past controversies, the present data enable the author to describe the histological changes of the thyroid gland after castration, in experiments with mice, in the following way: The same sequence occurs in both adult castration series, but apparently there is a time relation in these changes. The gradations of the changes found in the respective stages are of much interest and are associated with the age at castration. (1) The change in the first stage (rapid accumulation, static maximum storage and abrupt release of much colloid) is greater in magnitude in the late adult castration series than in the early series. (2) The change in the second stage (instability in colloid staining and cell activation of considerable degrees) is less in the late series than in the early series. (3) The change in the third stage (a trend toward colloid accumulation) is again greater in the late series than in the early series. A final word should be said concerning these changes. For the attainment of presumably endocrine readjustment in castrated animals, the three successive changes occur in the thyroid glands.

Two points have to be carefully considered in studies of histological changes of the thyroid glands after castration. Marked differences are identified as such in the present experiments on histometrical ground, and after repeated comparison of sequential events in both castration series with those in the control series, the present evidence appears sound. (1) A possible source of diversity of the data obtained by previous investigators is attributable to the choice of age at castration. If animals of unknown age are used for the experiments, no consistent result can obtained. One of the difficulties in obtaining a consistent view, which some of the investigators have experienced, lies in the fact that normal animals of different ages indicate different thyroid patterns qualitatively as well as quantitatively with considerably wide fluctuations even at the same age. (2) In addition, studies without comparison of at least two castration series may lead one to an one-sided conclusion, even when the choice of age at time of castration and duration of castration period is adequate.

\section{Summary and Conclusions}

Castration of mice at 50 and 100 days of age (early adult and late 
adult castration series) is followed by typical histological changes in the thyroid glands, and the histometrical measurements make it possible to divide their sequential changes into three stages.

The first stage lasting about 30 days (in the early adult castration series) or 40 days (in the late series) after castration is characterized by the abrupt increase of large follicles exceeding $50 \mu$ in diameter, in frequency per $\mathrm{mm}^{2}$, static maintenance of their maximum level and their rapid decrease to the normal range; concomitantly, a similar sequence of dark colloid is observed. This is evidently interpreted as showing rapid accumulation, static storage and abrupt release of much colloid.

The second stage after the previous stage to until about the 120th postoperative day, is marked by the continued maintenance of almost the same level in frequency as the normal for the large follicles, fluctuations in staining of colloid and cell activation of considerable degrees. The thyroid pattern in the castrates, especially in the early adult castrates, resembles that of the corresponding normal controls.

The third stage represents a trend toward colloid accumulation indicated by the occurrence of dark colloid, general decrease in cell height of follicle cells, further increase in frequency within the normal range of the large follicles and frequent occurrence of enormously grown follicles.

Concerning the degrees of these changes, there is apparently a time element related to the age at castration. In the late adult castration series, the change in the first stage greater in degree, that in the second smaller and that in the third greater again, while in the early series they are reversed.

No sex difference is found in the histological changes in the thyroid glands of both castration series.

Still another point of interest is that secretory droplets appear often in both castration series, but rare in the normal control series.

Prof. Dr. H. Nagamatsu died in November 26, 1953. The author is indebt to Prof. Nagamatsu for his kind help in the initial stages, and subsequently to Profs. Drs. Ch. Togari and $\mathrm{K}$. Yamada for their valuable help and advice in the completion of this work, and to Prof. Dr. S. Sugiyama, Nagoya City University Medical School, for his help. 


\section{Literature Cited}

Anderson, D. H. and H. S. Kennedy: J. Physiol., 79, 1, 1933.

Aron, M.: C. R. Soc. Biol., 103, 145, 1930.

- : C. R. Ass. Anat., 29, 7, 1934.

Bargmann, W.: Die Schilddrüse in v. Möllendorff's Handb. d. mikr. Anat., 6, 2T1, 1, Julius Springer, Berlin, 1939.

Benazzi, M.: Monit. zool. ital., 43, 222, 1933 (cited from Bargmann, 1939).

Betz, H.: C. R. Soc. Biol., 146, 325, 1952.

Chouke, K. S.: Endocrinology, 14, 12, 1930.

Cucco, G. P.: Fisiol. e med., 3, 1,1932 (cited from Salter, 1940).

De Robertis, E.: Anat. Rec., 84, 125, 1942.

De Robertis, E. and E. Del Conte: Rev. soc. argent. de biol, 20, 88, 1944 (cited from Dvoskin, 1947).

Dogliotti, V.: Ann. di ostet. eginec., 56, 547, 1934 (cited from Bargmann, 1939).

Dvoskin, S.: Endocrinology, 41, 220, 1947.

- : Endocrinology, 43, 52, 1948.

Florentin, P.: C. R. Soc. Biol., 102, 13, 1929.

Florentin, P., Th. Fontaine et L. Hennequin: C. R. Soc. Biol., 121, 1410, 1936.

Franke, M. et I. Ptaszek: C. R. Soc. Biol., 113, 1302, 1933.

- : C. R. Soc. Biol., 114, 1129, 1933.

Hay ashi, M.: Kaibogaku Zassi, 28, 3, 1953 (Japanese).

Hürthle, K.: Pflügers Arch., 56, 1, 1894.

Is himaru, S.: Fol. Anat. Jap., 4, 13, 1926.

Jackson, C. M. : Amer. J. Anat., 19, 305, 1916.

Kippen, A. A. and L. Loeb: Endocrinology, 20, 201, 1936,

Krogh, M. and H. Okkels: Bull. Hist., 10, 105, 1933.

Leblond, G. P. and J. Gross: Endocrinology, 43, 306, 1948.

Loeser, A.: Arch. f. exper. Path. u. Pharmakol,, 176, 697, 1934.

Mergier-Parot, L. et H. Tuchmann-Duplessis : C. R. Soc. Biol., 147, 951, 1953.

Morris, D. M.: Endocrinology, 50, 277, 1952.

Nadler, N. J., C. P. Leblond and R. Bogoroch: Enfocrinology, 54, 154, 1954.

Odell, T. T. Jr.: Endocrinology, 51, 265, 1952.

Paschkis, K. E., A. Cantarow and W. C. Peacock: Proc. Soc. Exp. Biol. Med., 18, 485, 1948.

Proto, M.: Policlinico, 41, 460, 1934 (cited from Bargmann, 1939).

Purves, H. P. and W. E. Griesbach: Endocrinology, 49, 244, 1951.

Ross, R.: Rouxs Arch., 137, 773, 1938 (cited from Bargmann, 1939).

Salter, W. H.: The endocrine function of iodine, Harvard University Press, Cambridge, 1940.

Schultze, A. B. and C. W. Turner: Mo. Agr. Exp. Sta. Res. Bul., 392, 1945 (cited from Odell, 1952).

Schultze, K. W.: Dtsch. med. Wschr., 61, 1041, 1935.

Selye, H.: Textbook of Endocrinology, 2nd Ed., 5th Printing, 690, Acta Endocrinològica Inc., Montreal, 1950.

Severinghaus, A. E.: Z. Zellforsch., 19, 653, 1933.

Siegel, A. N. and S. A. D'Angelo: Anat. Rec., 112, 431, 1952.

Starr, P. and R. C. Bruner: Proc. Soc. Exp. Biol. Med., 33, 465, 1935.

Sugiyama, S.: Nagoya Igakkai Zasshi, 50, 1171, 1939 (Japanese). 
- : Jap. J. Med. Sci., 1 Anat., 9, 18, 1942.

Sugigama, S. and T. Yagizawa : Fol. Anat. Jap., 23, 67, 1950.

Williams, R. G.: Amer. J. Anat., 62, 1, 1937.

\section{Explanation of Figures}

All figures except figure 9 represent photomicrographs of thyroid glands fixed in Kolster's fluid and stained with Heidenhain's iron hamatoxylin, $\times 100$.

4. Normal control series: 60 days of age. Female.

5. Early adult castration series: 10 days after castration ( 60 days of age). Female.

6. Early adult castration series: 60 days after castration (110 days of age). Male.

7. Normal control series: 110 days of age. Male.

8. Late adult castration series: 10 days after castration ( 110 days of age). Male.

9. Late adult castration series: 10 days after castration. Male. Numerous secretory droplets are seen. Ciaccio, Azan stain. $\times 700$. 
Plate I
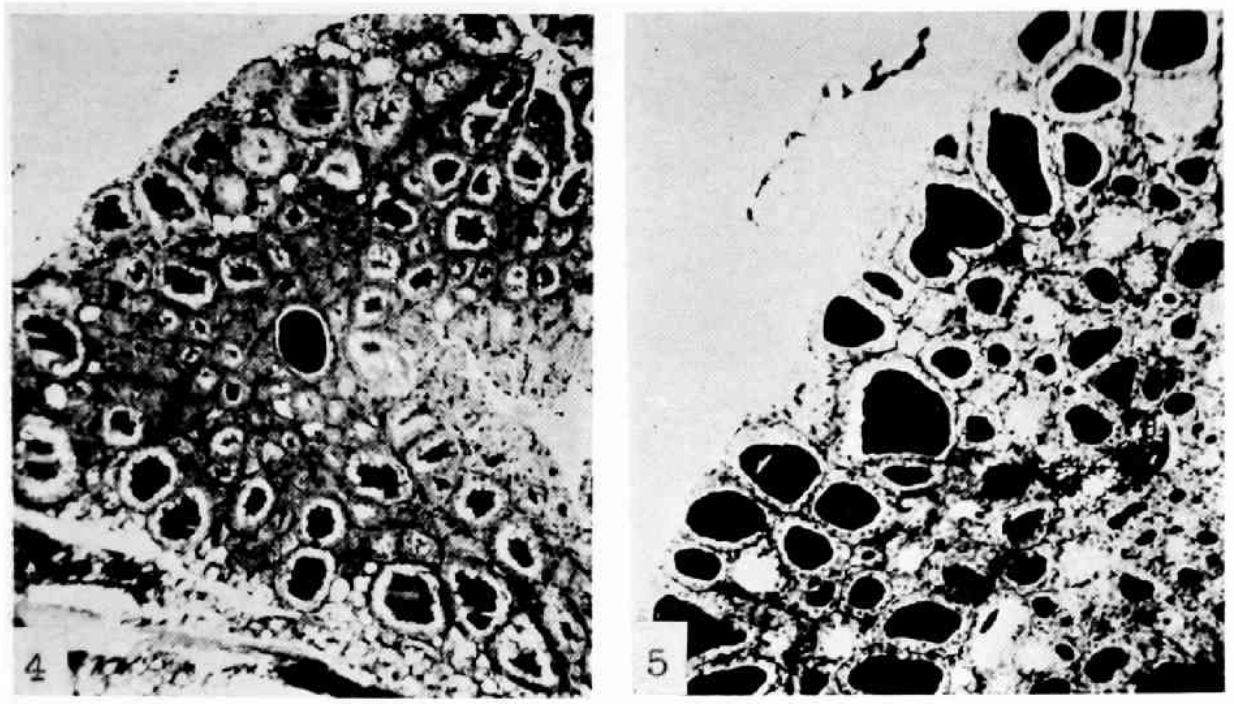

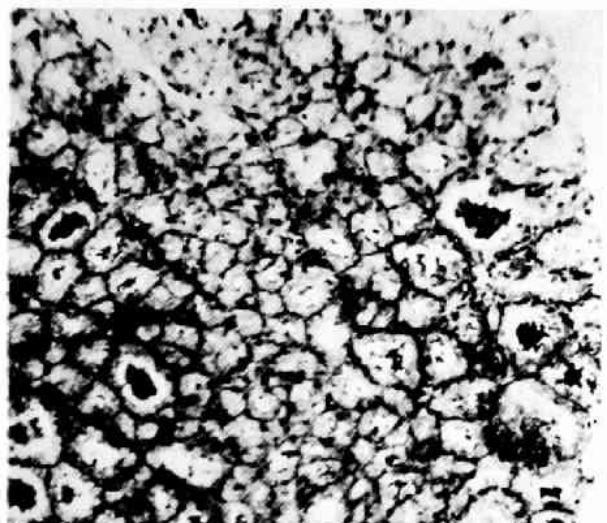
A.

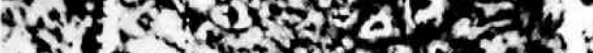

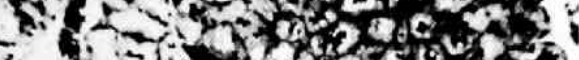

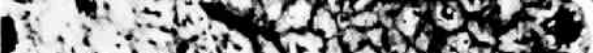

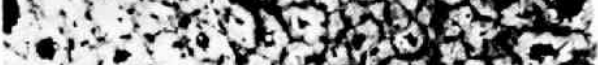

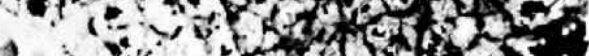

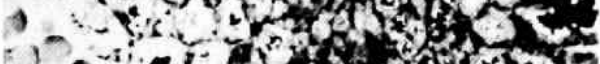

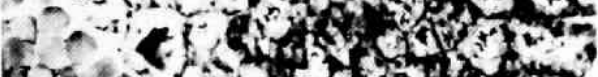

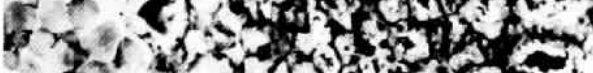

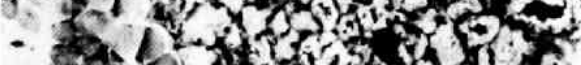

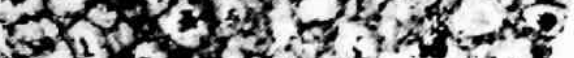

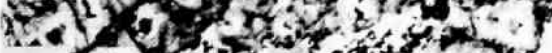

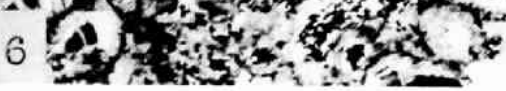

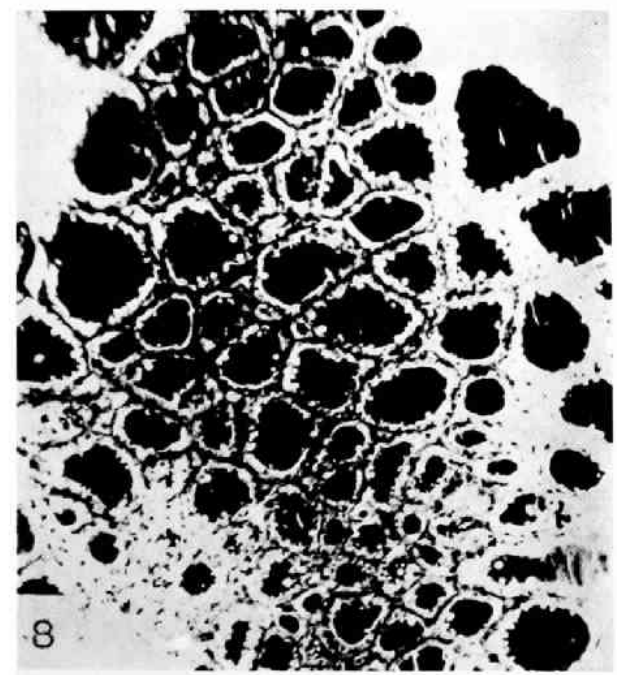

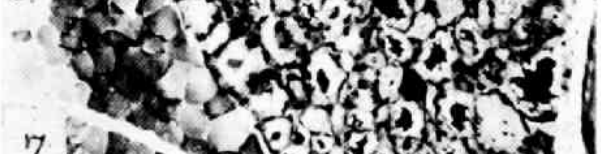

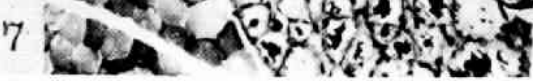

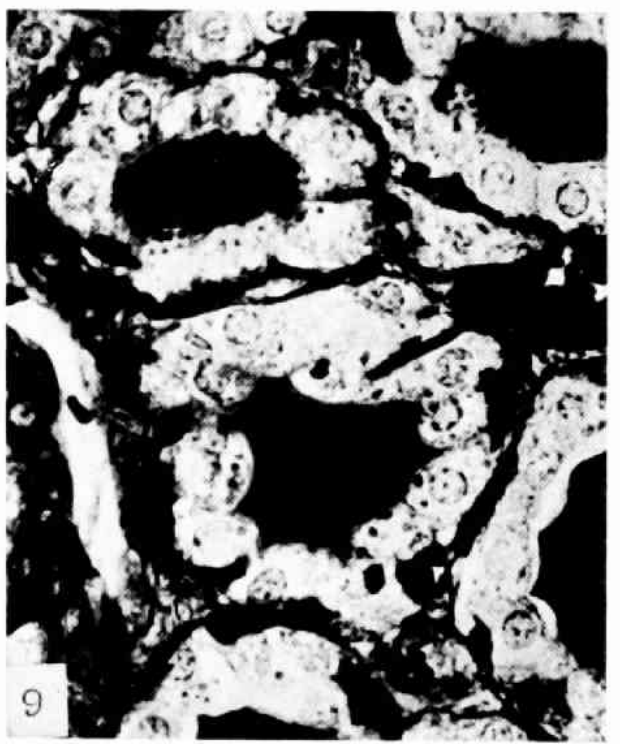

S. Ohida 